\title{
Is Transformational Leadership Region-Centric in Nature?
}

\author{
Niharika Gaan ${ }^{1}$ \& Prahlada Gaan ${ }^{2}$ \\ ${ }^{1}$ Management Development Institute- Murshidabad, West Bengal, India \\ ${ }^{2}$ National Aluminium Company Limited, India \\ Correspondence: Niharika Gaan, Assistant Professor (HR/OB) cum Chairperson of Student Welfare, \\ Management Development Institute, Murshidabad, DB-3, Sector-1, Salt Lake, Kolkata, West Bengal, 700064, \\ India. E-mail: niharika@mdim.ac.in
}

Received: January 3, 2014

Accepted: July 15, 2014

Online Published: July 25, 2014

doi:10.5539/ijbm.v9n8p108

URL: http://dx.doi.org/10.5539/ijbm.v9n8p108

\begin{abstract}
The study aims at examining the effective operationalization of transformational leadership style which is contingent upon regional culture. A qualitative approach using a single case revelatory method was adopted. Data were collected from a transformational leader, 22 employees of concerned companies, three district administrators and three suppliers who worked under the supervision of the leader and in the process of operations. The analysis revealed that successful a transformational leader is predisposed to maverick behaviour; building social capital, self-transcendence; the act of liaising between authorities, public and others stakeholders; a risk-taking ability coupled with operational expertise; and nurturant type leader with personal touch. The study draws the attention of scholars that transformational leadership is manifested in social milieu and is different from a universal model of transformational leadership. The paper concludes with a framework called "MSC TEC RESTL" to understand the phenomenon of transformational leadership which is culturally grounded.
\end{abstract}

Keywords: maverick, social capital, self-transcendence, transformational leadership, risk-taker cum technical wizardry, Odisha culture

\section{Introduction}

Transformational leadership is considered to bring about phenomenal change in any organizational outcomes (Anonymous, 2005; Erkutlu, 2008; Gill \& Mathur, 2007; Hinduan et al., 2009; Mwendia, 2006; Tracey \& Hinkin, 1994). It is also stated that the credit of organizational success and failure is attributed invariably to transformational leadership (Singh \& Bhandarkar, 1990). This noticeable change has been observed before the 1990s in the steel industry of India, when the industry was operating under a control regime. In this context, Singh and Bhandarkar (1990) made an intensive study by considering five Indian transformational leaders who had brought about substantial changes in the operating cultures of the organizations as well as in their performance. Other studies found that leaders' personal attributes influence the choices and the decisions they make in the organization (Carpenter, Geletkanycz, \& Sanders, 2004; Hambrick \& Mason, 1984), and, in turn, these decisions influence followers' attitudes and beliefs (Berson et al., 2008; Schein, 1992; Schneider, 1987). This idea has been less researched upon in the Indian context where subordinate behaviour has been seen to be sensitive to attributional syndromes (Singh \& Bhandarkar, 1990). Nonetheless, the study has even precluded the role of technocrat-holding positions at middle managerial levels towards tremendous change in organizational performance. After the 1990s, with privatization and globalization, certain studies on transformational leadership by Kanungo and Menon (2000) have found that the effectiveness of transformational leadership was felt by followers in terms of high collective identity, resulting in enhanced sense of reverence, trust and satisfaction with the leader. Yet another set of studies by Conger, Kanungo, and associates (1988) found that transformational leader behaviour, followers' performance, and satisfaction were significantly correlated. Further, the study by Singh and Krishnan (2005) stated that societal culture and national culture have ramifications on group processes like transformational leadership. Therefore, it can be inferred that certain idiosyncratic nature of the society and the region cannot be universalized in terms of national culture. This insight has been rarely cited in past literature.

However, despite the importance of a transformational leader ascribed to the topic of organizational change, there is a dearth of studies on personal attributes or behaviours influencing the performance of transformational 
leadership with regards to project commissioning in the metallurgical and power sectors. Looking at the backdrop of past literature, the present study aims at exploring certain behaviours of transformational leaders which espouse the value of a specific region or community while exerting tremendous impact on employee morale and organizational performance.

\section{Theoretical Overview}

Transformational leadership is defined as a leader's ability to motivate followers to prepare for change and execute organizational goal (Bass, 1985). Apparently, four distinct dimensions of leader behaviour are traditionally associated with transformational leadership: idealized influence and charisma; inspirational motivation; intellectual stimulation; and individualized consideration. The leaders not only create a vision for change but inspire followers by building up trust to achieve higher level of performance (Bass, 1985; George \& Jones, 2008; Griffin \& Moorhead, 2007; Kreitner \& Kinicki, 2007).

Institutionalizing a dramatic change and accelerating the agility of the organization through a new vision are considered to be hallmarks of transformational leadership (Seltzer \& Bass, 1990). Successful transformational leadership has also been seen in cases where the cultural ethos has been kept in mind (Smith \& Peterson, 2002).

The past literature reveals certain commonalities regarding the attributes defining transformational leadership. The leader is considered to embrace attributes like displaying empathy; dramatizing the mission; projecting self-assurance that enhances the leader's image; assuring followers of their competency; and providing followers with opportunities to experience success (Carpenter, Geletkanycz, \& Sanders, 2004; Hambrick \& Mason, 1984; Dayal, 1999; Sinha, 1995). Similarly, awareness of local culture plays a significant role in order to understand the true needs of followers as well as their underlying assumptions, beliefs and values (Kejriwal and Krishnan, 2004). Besides that, western ideologies and their alien value systems have contributed to inefficiencies in cultures such as in India (Kanungo \& Jaeger, 1990). Consequently, one of the studies in India made an attempt to develop a new scale to measure transformational leadership in Indian context (Singh \& Krishnan, 2005) and found the construct to be culture specific.

India is known to be a culturally diverse state. Hence, the researcher cannot follow any homogeneity of values based on few locations. In the study of Sinha and his associates (1994), it is inferred that except for a few values like familism, hierarchy and personalized relationships, the culture throughout India differs on a regional or location basis. If the transformational leadership is culturally contingent then, as per the previous statement, the development of scale to measure transformational leadership will differ on a location basis in India. In past literature, insight at a micro level discussion on transformational leadership has a nominal say on the nuances of regional or national culture which influence the values and behaviours of leaders. Subsequently, the effect is realized in terms of the reactions of followers in the organizations (Singh \& Krishnan, 2005). Therefore, the identified gap in the literature indicates firmly as to how regional culture has ramifications on transformational leaders' performance. Therefore, a preliminary look has been provided in the present study on behavioural manifestations of transformational leadership that are idiosyncratic to Odisha culture.

\subsection{Odisha Culture}

Every state or community has invariably evolved from a specific cult which has usage, belief and traditions. Hence, of all the regional cultures, Odisha, or the ancient Kalinga Empire, played a very predominant and vital role in the cultural matrix of Indian civilization. Situated on the eastern coast of India, the state of Odisha has succeeded in developing a distinct identity of its own in the realms of creative arts. Odisha culture has a three-tiered structure with interfaces and interpolation, the tribal/ethnic, the folk/peasant and the urban/classical which existed side by side enriching and enlarging the cultural dimensions. The espoused values, rituals, and folklores of Odisha have been strongly influenced by maritime trade of early and medieval periodin the history of it (Dash, 2011). In ancient times, coastal lines to cities like Tamralipti, Dantapura, Palur, and Kalinganagara opened up channels of overseas trade and cultural exchanges with the countries of South East Asia, like Bali, Java, Sumatra, and Suvarnadipa. It is argued that these maritime activities epitomize the adventurous nature and risk-taking ability of Odisha community members (Nanda, 2006).

Odisha culture is otherwise known as culture of "Lord Jagannath", the presiding deity of Puri and a prominent symbol of the ancient Hindu kingdom. Odisha's art, literature and music were influenced immensely by the Sri Jagannath culture as was the socio-religious and economic life of the Odisha people in particular. One of the major salient features of the culture of Lord Jagannath is "Sahinshilata" or tolerance, a value that contributes in its specific way to human welfare in Odisha (Mohanty, 2005). Humbleness or "Vinamrata" is another cardinal human value amply prevalent here. The culture of Lord Jagannath always takes a positive view of the life; it does not attend to pessimistic thoughts of grief, suffering and death. It recommends a strong faith in the Divine. 
It teaches man to strive for perfection of the soul by the sacrifice of the self or "Atmabali daba". Worldly pursuits find no place in the culture of Lord Jagannath; the devotees pray for divine life but not for material gain (Mohanty, 2005).The culture of Lord Jagannath has effected unity in diversity by faith and integrated human society with the help of human values. The social body fabric of each Odisha people is thus woven around the culture of Lord Jagannath in varied hues and into an excellent synthesis of spiritual ethos.

Besides that, the legends like Sarla Das, Loknath Bidyadhar, Purusottam Das, Baladev Badajena, Dr. H.K.Mahatab and many others who were popular in the field of literature brought about revolutionary change in the state of Odisha and changed the fabric of society through their writings in poetry and novels. Their act symbolizes the maverick nature of Odisha people in general (Das, 2009).

The Odisha culture stands for its religious catholicity and tolerance, resulting in the assimilation of the tenets of all mainstream Indian religions like Buddhism, Jainism, Saivism, Tantricism and Vaisnavism into the eclectic cult of Lord Jagannath (Das, 2009).

The next section deals with method of Yin (2008) adopted to explore the values of the society grounded in the behaviour of the TL. The results of the study will help us to map a behavioural profile of TL in societal context and will reveal how remotely it stands to the operationalization of the TL in Indian context.

\section{Research Method}

The study follows the method applied in the study by Yin (2008) wherein a single case revelatory study concept is emphasized. Therefore, the present elucidation of a case study replicates Yin's protocol for conducting single case study. Data have been collected from a transformational leader, his subordinates of the organizations as well as suppliers concerned with the organizations served by the leader. The study is a longitudinal based intensive case study over a period of more than three years. The focus on a single leader allows us a more in-depth study of the phenomenon. This approach is also consistent with some prior studies that focused on single leaders (e.g. Browning et al., 1995; McMullen \& Adobor, 2010).

\subsection{Research Context}

After Independence, India's visionary leader Prime Minister Jawaharlal Nehru wanted India to be self-sufficient in steel as one of the prime infrastructure building materials. As a result, three public sector steel plants were set up at Rourkela in Odisha, Bhilai in the then Madhya Pradesh (now Chhattisgarh state) and Durgapur in West Bengal. The Bokaro steel plant was established in Bihar (now Jharkhand state). All these states were rich in high grade iron ore reserve.

The Steel Authority of India (SAIL) is the largest public sector, or state-owned, steel makers in India, with an annual capacity of 13.5 million metric tonnes. The leader had served Rourkela and Bokaro Steel Plants at the initial phase of their commissioning.

Incorporated in 1981, the National Aluminium Corporation (NALCO), situated in the east coast of Orissa, is a Public Sector unit with the capacity to manufacture aluminium of 345,000 tonnes per annum (tpa). The mining area of NALCO is located at Damonjodi, whereas its captive power plant (CPP) and manufacturing site "smelter" are located at Angul. With advanced state-of-art-technology smelting and pollution control, NALCO has earned a reputation of producing aluminium of competitive quality worldwide. After leaving SAIL, an offer was made by NALCO to induct the leader into the operations, owing to his immense technical expertise in setting up a power plant.

The Visakhapatnam Steel Plant, located at Visakhapatnam, Andhra Pradesh and built with an annual production capacity of 3.0 million tonnes, is the only shore-based Integrated Steel Plant. Known popularly as Vizag Steel, the plant has been a symbol of innovativeness and excellence right from its nascent stage and is consistently producing well above 3.5 Mtpy (Mega tonnes per year). In 1982, Vizag Steel was separated from SAIL to attain a separate corporate entity called Rastriya Ispat Nigam Limited (RINL). The leader also served with Vizag Steel during his last years of service tenure. Incidentally, the leader was brought on board during the formative stage of Vizag Steel's set-up, when its growth was dependent significantly upon the leader's contribution.

\subsubsection{Background of the Leader}

The leader was an electrical engineer by choice. He completed B. Tech. (Hons) in 1955 and was among the first batch of the first Indian Institute of Technology (IIT) in Kharagpur, West Bengal. Owing to his profound brightness and being ranked first in the batch of 10 graduate engineers, he was selected for the then Hindustan Steel Limited, now popularly called SAIL. He received a two-year training stint at the TISCO technical institute and earned his postgraduate diploma in electrical, mechanical and metallurgical engineering with distinction. 
Subsequently, he was deputed to West Germany for an advanced training programme at the Rheinhanser steel works, Seimens Wiltex and GHH. Having completed his training abroad, he started as a junior engineer in the 128 MW captive power plant of Rourkela Steel Plant. Hence, his formative years were spent in SAIL and later on in some of the well-known Indian metallurgical organizations carrying worldwide fame and popularity.

\subsection{Data Collection}

Data were gathered through e-mails shot to the leader while he was in a critical condition due to illness. He was taking his last breath when the author approached him. Nevertheless, he cooperated with the author to share some of the opinions towards his leadership style. Long mails were exchanged with the leader along with back and forth conversations which included an in-depth interview conducted in five phases over a period of six months. The perspectives of the subordinates working with SAIL, NALCO and Vizag Steel were assembled through direct interviews and through their observations, too. When the author was on an official tour to the respective sites in consulting matters, data were collected from the 22 employees holding higher positions. Even three suppliers to the respective companies were consulted and interviewed to share their opinion about the leader's style. The state administrators who were strongly acquainted with the leader were approached to understand their perception of his leadership style. Thus the data collection period got elongated to three years or so due to unavailability of respondents at the time of short stay of the author in respective places. All the interviews were audio taped and transcribed in their entirety. Mental field notes were made and recorded after each interview. In a few cases, follow-up phone interviews were conducted to seek clarification.

\subsection{Data Analysis}

The most commonly borrowed elements from traditional grounded theory (Strauss and Glaser, 1990) are the coding techniques (open, axial, and selective) used to analyse data. In all, over 114 pages of interviews and discussions were transcribed. Drawing from the grounded theory, open coding techniques (Annells, 1990; Baskerville and Pries-Heje, 1999) were used. The transcript was perused manually and one or more conceptual codes were assigned to each line, sentence, or paragraph, most often in terms of properties and dimensions. During analysis, axial coding was used to put data together in new ways, by seeking to identify causal relationships between categories. Codes were merged, changed, and occasionally eliminated. Based on similarities or differences, as well as emerging relationships, codes were grouped into clusters called conceptual categories, representing a higher level of abstraction.

\section{Results}

The leader's journey as a successful transformational leader has been portrayed from the time when he was holding the post of chief engineer at Rourkela Steel plant to a position of Chairman-cum-Managing Director of the Vizag steel plant. The leader's behaviours, like technical wizardry, maverick nature, people-employee concern, self-transcendence and liaising role with stakeholders, have been invariably considered as the cause of making a significant impact on organizational outcomes. This has been evaluated by examining the primary data available through respondents. The leader's outstanding contributions to the steel and power sector have led him to achieve various awards and accolades bestowed upon him by government, professional and social associations operating at the national and international levels:

- Arch of India Gold awards from NRI Institute in their $5^{\text {th }}$ international conference of Indians and NRIs in Detroit USA held in June 1992;

- Indira Gandhi Memorial national award from the Institute of Economic Studies in 1991 from the A.P. Public sector Employee Federation as best chief executive;

- Udyog Ratna Award from the Institute of Economic studies at New Delhi in October 1992;

- Jawaharlal Nehru Excellence Award from the Institute of Economic studies in November 1992; and

- Manager of the Year award by the Rotary Club, Waltair, Andhra Pradesh in November 1992.

\subsection{Key Findings on Influence Behaviour}

An insight into key behaviours of a leader which have eventually resulted in an increase in performance of transformational leadership is represented in Table1.

\subsubsection{Transformational Leader as Maverick}

There are several situations quoted by respondents which provide an insight into the maverick nature of a transformational leader. Maverick is the kind of person who champions cause and takes an independent stance without any hierarchical support. The kinds of advocacy behaviours identified in this transformational leader 
seemed consistent with earlier work on maverick attribute (Ray, Ugbah, Brammer, and DeWine, 1996). These studies discussed the attributes of maverick leaders as the crucial characteristics that enable change to occur. Maverick leaders fight the status quo to test the limits of the environment and thereby help to establish a culture that expects change. There are four main ways which have been identified to demonstrate maverick behaviour in the present study.

Firstly, an incident in this study showcases the leader to be championing the culture of motivation in Bokaro Steel Plant (BSL). A sagging culture was experienced by the leader when he joined as deputy general manager at BSL. The maintenance engineers were downplayed by production engineers, the former treated as roadside mechanics by the latter. However, the leader's strong objections and vehement pleadings in the morning meetings, with convincing presentations, gradually mellowed the attitude of the production chief towards maintenance engineers. The repercussions of his initiatives resulted in the acknowledgement of the contribution and dedication of the maintenance engineers, allocation of adequate budget for timely repair and maintenance of machines, decline of fire fighting and a dramatic improvement in plant productivity. Maintenance engineers were accorded timely promotion due to the leader's endeavour and initiation.

Secondly, the respondent cited an incident of maverick approach of a leader during his reign as general manager in NALCO. The smelter plant was a part of NALCO, planned in collaboration with Aluminium Pechiney, France, and the engineers were sent overseas to countries like France and Australia for advanced training programmes. On the other hand, in the CPP (Captive Power Plant), another site of NALCO, the engineers had no scope of receiving advanced training programmes due to the inherent nature of the power plant being more indigenous. Nevertheless, the leader took the initiative to reduce this gap and send CPP engineers to Germany for training in data acquisition system at KWU Works, the technical collaborators of M/S BHEL in turbines and generators, and Westinghouse Corporation of USA. Some engineers were sent to UK for receiving training programmes under the Colombo Plan. These initiatives of the leader served as a grievance redresser of CPP engineers to some extent. Other divisive policies of the organization bringing a great divide between CPP and Smelter employees, for instance the smelter unit had planned a sprawling colony for the employees with fashionable two storied bungalows and in close proximity to the plant and which was not provided to CPP employees were changed with great intervention by the leader. Thus championing the cause by bringing uniformity in organizational policy of NALCO the leader tried in restoring the legitimate rights of the CPP employees resulting in culture of cohesion and cooperation from those of biasness and prejudices.

Thirdly, to work towards the interest of the project, the leader deviated from company policy and sent engineers to inspect and expedite various manufacturers' work by letting them avail air travel facility for which they were not eligible. The compounded results were reflected in maintaining higher standards and quality of project. Finally, speaking of the leader, one of the senior employees stated:

Although he worked in Public Sector Undertakings (PSUs) which used to follow formal practices, he managed in hiring his own set of colleagues by adopting lateral hiring practice (and hence his colleagues believed that doing so was going to be impossible), who were dedicated to organizational interest and competent with technical, commercial and people skills (this was achieved both in Nalco, Angul, and VSP,Vishakapatnam). He traversed through uncharted course and his method of lateral recruitment facilitated to a great degree the capability of the organizations to execute the huge projects at the time of commissioning in a timely manner and to operate them efficiently thereafter...

On the whole, data revealed that the leader had championed causes and taken initiatives which used to be steered by persons holding key position in organization unlike his status. Most importantly the employee morale was restored through his sheer belief and effort. The ideas of growth and development through international-based exposure were incredible and consistently advocated through his various developmental activities. The unfathomed need of the employees was addressed by the leader though through slight deviation from company policies.

In consonance with aforementioned findings, the folklore and popular sayings about the sea voyages of the merchants of Odisha in the past have been presented by the nationalist historians in the first phase of the 20th century A.D. (Roy, 1932; Kara, 1931; Shasmal, 1946; Singh, 1929). Folktales of Odisha like "Humane Revolutionary" have more often demonstrated the maverick nature of the Odisha community's members and leaders. The most dramatic illustration in recent times is that of Biju Patnaik, who was known for adventurous achievements. He braved all hazards after being entrusted by the then Prime Minister Jawaharlal Nehru with the responsibility of rescuing Sjahrir from the clutch of dutch as they had launched attack on Indonesia on large scale. He even brought about revolutionary change in the state of Odisha by revising the state economic policies 
during his stint as a chief minister of the state.

Thus, the aforementioned discussions lead to following propositions:

Pla: The maverick nature of a leader will positively impact the performance of a transformational leader.

P1b: The maverick nature of a transformational leader will make a positive impact on the culture of the organization.

Table1. Perceptions of employees and stakeholders towards leadership behaviour

\begin{tabular}{|c|c|c|}
\hline Items & Illustrative Quotations & Respondent \\
\hline Social capital & $\begin{array}{l}\text { "Mr. B.N Rath could convince and obtain the support of the top management to } \\
\text { recruit engineers from SAIL, FCI and other established public and private sector } \\
\text { organizations who were his trusted lieutnanats or otherwise known to him which paid } \\
\text { good dividends in commissioning of the plant as per schedule without time and cost } \\
\text { overrun". } \\
\text { "Known devil is better than unknown angel" was the principle adopted by him }\end{array}$ & Senior Manager \\
\hline Maverick & $\begin{array}{l}\text { "While in his reign as Chairman cum Managing director in Vizag Steel Plant, } \\
\text { doubling its capacity to } 6.3 \text { MT of steel production was conceived and was a big } \\
\text { challenge. Eventually, it got approved by the government. He even initiated a deep } \\
\text { water port at Gangavaran which materialized in } 2008 \text { for importing raw material like } \\
\text { coking coal, supplying iron ore and exporting its products abroad". This initiation } \\
\text { seemed to be beyond one's imagination. }\end{array}$ & General Manager \\
\hline \multirow[t]{2}{*}{ Self Transcendence } & $\begin{array}{l}\text { "He showed remarkable foresight to realize that the fate of the plant was interlinked } \\
\text { with that of the society around it. He believed in empowerment of women and also } \\
\text { encouraged the youth to excel not only in academics but also in sports, by providing } \\
\text { them with sports facilities. This concept is today gaining importance as a management } \\
\text { practice called CSR - Corporate Social Responsibility". }\end{array}$ & $\begin{array}{l}\text { Chief managing } \\
\text { director }\end{array}$ \\
\hline & $\begin{array}{l}\text { His condescending attitude while dealing with trade unions had earned a wide } \\
\text { popularity among them. They happily used to follow his instructions to complete the } \\
\text { project well in ahead at CPP (NALCO). }\end{array}$ & $\begin{array}{l}\text { Deputy } \\
\text { manager }\end{array}$ \\
\hline $\begin{array}{l}\text { Nurturant approach with } \\
\text { personal touch }\end{array}$ & $\begin{array}{l}\text { "Apart from his technical skill and expertise he was a good man manager. He was } \\
\text { workaholic and tough task master no doubt behind this tough facade of Sri Rath was a } \\
\text { kind and compassionate, sociable personality who could pull, not push his team } \\
\text { members for achieving a target without the feeling of fatigue and discontent. } \\
\text { When there was any problem in the family of his team members Rath used to visit } \\
\text { like a father figure and make arrangements, be it taking the ailing to the hospital or } \\
\text { arranging for cremation in case of death of any family member of employees". }\end{array}$ & Senior Manager \\
\hline Act of Liaising & $\begin{array}{l}\text { "Rath developed good rapport with the officials of the district and state administration } \\
\text { which helped in tackling the local land acquisition and other problems". } \\
\text { Once there was large scale labour unrest at NALCO. The leader was able to leverage } \\
\text { his personal relationships with the labour union leaders, the government of Odisha, } \\
\text { minister in the Odisha Government who was from a constituency close to CPP } \\
\text { vicinity, and district administration officials to quell the agitation. }\end{array}$ & $\begin{array}{l}\text { Close compatriot and } \\
\text { employee of NALCO }\end{array}$ \\
\hline $\begin{array}{l}\text { Risk Taker cum Technical } \\
\text { Wizardry }\end{array}$ & $\begin{array}{l}\text { "After } 28 \text { years in SAIL, Sri Rath took a professional risk to move to a sophisticated } \\
\text { steel plant to NALCO's CPP which was then a captive power plant at ground level. } \\
\text { He had to face innumerable obstacles by way of agitations against land acquisition, } \\
\text { water supply and a railway line between the power plant and the captive coal mine. } \\
\text { He and his team tackled this by evolving strategies to win over the faith and } \\
\text { confidence of the agitating parties as well commissioning the plant well in ahead of } \\
\text { schedule. Technological sophistication was inherent in this organization owing to } \\
\text { Mr.Rath's technical expertise gained in SAIL plants at RSP and BSL." }\end{array}$ & $\begin{array}{l}\text { Deputy } \\
\text { manager }\end{array}$ \\
\hline
\end{tabular}




\subsubsection{Reliance on Social Capital}

The study here revealed that the transformational leader was dependant on personal relationships, and the goodwill and trust he built and nurtured with the stakeholders as a way of creating reciprocity. Adler and Kwon (2002) define social capital as the leader setting up goodwill of the organization for the outsiders (Acquaah 2007; Peng \& Luo, 2000; Nahapiet \& Ghoshal 1998).

The data here revealed that the transformational leader created obligations and a benign form of influence by building relational assets such as trust and affection as well as a sense of reciprocity on the part of the employees by his willingness to go out of his way to show favour to individual employees. Respondents consistently noted that the transformational leader seemed willing to do personal favours which indicated towards social capital reliance behaviour.

In the words of one of the employees of RSP:

Rath was recalled to RSP in 1983 in view of a serious power shortage situation and with his able co-ordination effort with state grid officials of the time he could manage greater share of power from the grid and RSP's production picked up.

Firstly, during his comeback to RSP, the leader succeeded well in negotiating with the Odisha state electricity board (OSEB) to secure the required quantity of power from the state grid.

Secondly in NALCO, he arranged and voluntarily participated in several social events to increase the solidarity among the employees of both the units. One of his subordinates, designated as executive director, put it in this way:

Leaders used to harness social forces in the organization to shape value system...He hired all the known people from his network while setting up NALCO. This could instantly build a very cohesive task force whose aim was to set up power plant in ahead of schedule... To our surprise it happened too...

Thirdly while his reign in VSP he used to arrange various business gatherings to build social relationships where members used to herald from different walk of life like corporate heads, suppliers to VSP and bureaucrats of Andhra Pradesh. The leader's frequent interactions with the stakeholders and presence at social events such as celebration of local festivals with the community members all afforded him the opportunity to build a web of social relations that became the bedrock.

Historically, it is observed that the Konark temple was planned and executed by one Langula Narsinghadev, the then king of Odisha, who employed his ministers like Sibei Samantray as the CEO of the project. The minister was unable to plan the task involving logistics engineering, construction management, and commissioning. But his ability to mobilize and organize the effort and support of 1200 sculptors and carpenters for 16 long years led to the completion of the temple against all odds eventually (Das, 2009).

Thus from the above findings the study proposes:

P2: Reliance on social capital increases the performance of transformational leadership.

\subsubsection{Act of Liaising}

Our analysis unfolded the act of liaising as an important dimension of transformational leadership. Firstly, the leader found the situation quite grave at the time of joining CPP as general manager. The construction of a water supply line, coal supply, merry-go-round system, ash pond, and ash disposal lines, were all activities outside the plant's boundary, posing a herculean challenge for him as surrounding villagers were litigant in nature; the first task he had to undertake was resolving the land acquisition problems. However, owing to a good rapport with the officials of the district and state administration, the leader could tackle the local land acquisition and other problems while at NALCO.

One of the senior most district administrators has stated:

"If officials at district level were not cooperating, he would try to establish cordial relationship with their bosses at the state level so that ultimately local officials were falling in line."

The second incident occurred when he joined Vizag Steel as Chief Managing Director in 1987.The government of India was not able to provide enough funds to the plant for expediting its construction activities. It was a great challenge for the leader to meet deadlines and achieve any critical milestones in such a situation. All the operational activities were demobilized. The leader worked out revised contract packages in consultation with manufacturing and equipment supplying agencies, like BHEL, HEC, Seimens, AEG, and Typazprome export of USSR, and took extra contractual steps to sustain the Hindustan Steel Works Construction Company to enable it 
to speed up the construction tempo.

Thirdly, in order to keep amicable environment an informal gathering consisting of officials from the personnel department and key union leaders were often assembled for expedition's purpose for instance angling expeditions nearby Tikarpada, the famous crocodile sanctuary on the banks of the River Mahanadi, were commendable. Thus he earned the goodwill of the union leaders and later used to stay quite reticent towards disturbed industrial relations.

In the opinion of the leader's successor at VSP:

The leader was involved in Yelluru Canal right from the conceptualization, planning, allocation of funding to coordinating with various agencies to get the ambitious canal project executed. It was important for the running of VSP. It meant much more than liaison - he made numerous visits to Hyderabad to convince the CM, Chief Secretary, other senior bureaucrats and district administration officials. Meanwhile, many of the officials changed and his visit had to be repeated with the new person holding the office to get the project to be completed. Today, this project is a lifeline for VSP, Vishakapatnam, as the huge steel plant requires huge quantities of fresh water.

Finally, one of the top management remarked that:

During his stint as a Chief Managing Director of VSP, he faced large-scale labour unrest initiated by labour unions in the early period of its operations. The leader could immediately resolve the critical issue by convincing the labour union leaders, while leveraging contacts at the political level in Delhi and Hyderabad [the labour unions had political affiliations] to avert a strike, which would have had a severe impact upon the financial position of the company. He was also able to line up sufficient support from the administration officials including the local police to manage any untoward incidents. Fortunately, all his efforts succeeded and the strike was averted.

The aforementioned demonstrated behaviour is consistent with the study by Yukl and Becker (2006) that showed that a leader is competent only when he serves as a liaison towards different stakeholders. He not only creates a culture of trust, goodwill and affection but has the competence to negotiate with stakeholders in the interest of the organization.

The dimension of the act of liaising recurred repeatedly here and much emphasis was given by the respondents from Odisha as this being a unique flavour to cultural dimension. In addition, the maritime relationship of Odisha state in the sixth century B.C. with Java, Bali, Sumatra, Borneo, Indonesia, Thailand, Burma, Ceylon, and China and after the ninth century with Arabia, Greece, and even west Africa bears the testimony of an act of liaising (Nanda, 2006; Mohanty, 2011).

Subsequently the proposition follows as:

\section{P3: The role of liaising significantly influences the performance of transformational leadership.}

\subsubsection{Self-Transcendence}

The act of looking at the welfare of others is known as self-transcendence (Schwartz, 2005a, 2005b). A study by Carey (2002) has asserted that the transformational leader could be presented as a moral leader who not only works towards the development of the follower but also remains people-centred to pursue common-end values. There are instances in this study which confirm the leader as being very modest, kind hearted and committed selflessly towards the employees and interested stakeholders. These very qualities subdued the protest of the community during commissioning of the projects in NALCO as well as in Vizag Steel.

Firstly, as part of corporate social responsibility, a voluntary effort was shown by the leader towards the renovation and development of villagers' school buildings, roads, clubs and amusement centres, distribution of television sets to community centres, provision of drinking water by sinking tube wells, and speedy and sincere compensation for crop losses due to construction activities. The employment was ensured to a person from each displaced family member falling within a 20-kilometre radius of the project, thereby restoring the community welfare and rehabilitation activity.

Secondly, on holidays, the leader would tour the neighbouring villages along with his administrators and public relations men to persuade the villagers to adopt poultry and cattle-rearing activities. Veterinary doctors often used to be arranged for conducting on-the-spot consultation sessions, which enthused the villagers to do cattle ranching with perfection.

The successor of the leader at VSP stated: 
During Rath's tenure as CMD (chief managing director), VSP reached out to the adjoining peripheral areas of a 20-kilometre radius to assist the villages in getting free drinking water supplies from bore well work by VSP. Villagers near the steel plant were adopted by the VSP management and the ladies' club of VSP under Mrs. Rath's leadership patronized them by running schools, conducting health camps, distributing clothes to the needy and poor,and donating sewing machines to underprivileged poor women to earn their livelihood by way of self-employment... Rath encouraged tree plantation in VSP township neighbouring areas by planting at least one tree for every tonne of steel plant production and the barren arid area became lush green...

One of the general managers stated:

The leader won the hearts of the community members by being benevolent and forward-looking. He was not only concerned for the commissioning of the project wherever he was assigned during his posting but also sensitive and concerned for the well-being of the surrounding community which were affected by projects.

Consistent with the present findings, it is seen historically that the blind saint Bhima Bhoi (2006) through his writings and poems in Odisha literature had stated: "The distress of people, the unfathomable sorrow, seeing who can bear, Let my life be in hell, but may the world be saved forever." Similarly, illustrations of self-transcendence among modern Odisha leadership had been found in leaders like Gopabandhu Das, Gopabandhu Chaudhury and Nabakrishna Chaudhury, who sacrificed their lucrative personal careers while in administrative positions of the state government and joined the Independence movement and "Bhoodan" (donation of land) movement to serve the people of Odisha and India at large (Das, 2009).

Gopabandhu Das has written in one of his patriotic poems:

"Let my body perish in the soil of this country, let my countrymen over my back walk on.

All the potholes on the path to freedom of my country, may those be filled up with my flesh and bone."

Hence, it is aptly said that the sage Bhima Bhoi and freedom fighter social worker Gopabandhu are two star exemplary figures of great transformational leaders in the firmament of Odisha in their times, exhibiting the trait of self-transcendence for the liberation of common mass. Interestingly, it is observed that living for selfless personal values is even valued at the national level (Singh \& Bhandhaker, 1988, Gupta, 1991).In similar vein, the leader here seems to apparently develop a more holistic and interconnected perspective, recognizing a synchronicity to life and developing a sense of commitment to others.

The evidence and discussion leads to our next proposition:

P4: Self-transcendence will significantly influence the performance of transformational leadership.

\subsubsection{Risk-Taker-cum-Technical Wizard}

The leader used to resolve operational problems with decisiveness, firmness and his risk-taking abilities. The followers considered the leader as a one-stop solution. This is possibly a case of attribution perceived by followers (Lord \& Emrich, 2001) in transformational leadership and the subsequent perceived performance is accelerated through the risk-taking approach (Singh \& Krishnan, 2005). The data in this study is consistent with past literature about the leader's perceived behaviour to be a risk-taker and technical wizard.

Firstly, when the leader came back to RSP (Rourkela steel plant) as Deputy General Manager, the plant was suffering from an acute problem of low frequency grid operations. This was leading to frequent turbine failure. As a technical wizard, he introduced innovative relay coordination schemes between RSP and CPP and the Odisha state grid so that power availability to the plant was maximized and turbine breakdown could be minimised in order to improve operational efficiency. This is further attributed to his idea of islanding during very low frequency grid operations.

Additionally, the CPP, with the most sophisticated state-of-the-art boilers and turbines, used to be run by young engineers fresh from college and having undergone six months on the job training program under the supervision of leader along with his mentorship. His policy of empowering employees placed at lower level and middle managerial level along with his mentorship helped them to regain managerial responsibilities and rediscover managerial authority without much dependency on hired experts or consultants, which other NALCO units did not do. Thus risk associated with his policy of empowerment paid rich dividends later on.

Secondly, speaking on the issue of risk-taking ability and technical wizardry, the executive director of NALCO stated:

He would inspect the plant premises indefatigably to see the proposals of work, take feedback from the workmen and engineers by practically visiting all construction fronts, conversing with the consultants, engineers and 
contractors, and listening carefully and attentively to their suggestions. He would address all technical problems at ten o'clock morning with his observations and feedback noted in the form of report containing detailed instructions to take corrective and remedial measures. Wherever necessary, in the afternoon hours he would visit the intake pump house and pipeline with one or two officials of the personnel and administration department which was falling in the vicinity of community surrounding the plant. He would give on-the-spot technical decisions in order to mitigate the affected villagers' complaints and problems, apparently seem to be risky.

Thirdly, the CMD of Vizag steel plant, the successor of the leader said:

He took a bold decision of starting the blowing of the first blast furnace 'Godavari', setting up a milestone deadline on 28 March 1990. The task had seemed to be impossible in the beginning and the hurdles invincible. But Rath's leadership, and his technical expertise have helped in pulling up the resources, making close follow-up, co-ordination and total control of the situation. On the whole, it eventually could accomplish the target to the satisfaction and relief of all associated with the gigantic task. With Rath's motive as a guiding force and he being leading from the front, things went on happening one after another in quick succession like the commissioning of the power plant's oxygen plant, the coke oven battery and all the units of 1.5 MT stage-they all were completed by November 1990 with a total financial implications of 8,500 crores of rupees...

Adding to the leader's predicament and stumbling blocks, the Andhra Pradesh Government had failed to complete the Ellura water supply scheme which was expected to supply the cooling water requirements of the steel plant. The leader worked out special packages and took up the construction of an open channel water canal system under direct supervision of the Vizag Steel and finally the system was made operational in 1991.

In medieval times, merchants of Odisha, called 'sadhavas' or bands of adventurous sailors, were acclaimed as "Kalinga sahasikah" (the brave Kalingans). Such adventurous voyages were possible due to technical wizardry like sailing ships using wind power. Large sails made of cloth were designed and built by Odisha craftsmen both for the boats in harbour and those being sailed from river ports along the Odisha sea coast. These adventurous tasks and risk taking abilities were attributes of the transformational leadership at medieval period (Nanda, 2006; Dash, 2011). The technical wizardry as an attribute to transformational leader has been referred to in one of the studies in the Indian context as "expertise" (Singh and Krishnan, 2005) and is confirmed in Odisha context too.

Based on preceding discussions, the study proposes:

P5a: A leader with the disposition of a risk-taker would significantly influence the performance of an organization.

P5b: Technical wizardry coupled with risk-taking ability would significantly influence the performance of the transformational leader at the stage of commissioning of the plant.

\subsection{6 "Nurturant" with Personal Touch}

The data in this study even revealed that followers provided recurring emphasis upon the leader's nurturant behaviour and personal touch for his employees, thereby confirming findings in past studies (Sinha, 1995; Singh and Bhandarkar, 1998; Singh and Krishnan, 2005). Nurturant type leaders are those who are caring, dependable, and yet authoritative and strict father like figures. They empower their follower yet they retain mantle of quintessential a mentor. Firstly, transformational contribution at RSP's power plant in transforming a workforce with an agrarian background into a skilled workforce was noteworthy. The technical architecture of RSP involved German power technology. The leader established a good rapport with German engineers and technicians. Being active members of German club availed their goodwill to train Indian engineers and workmen on the nuances of operations and maintenance of sophisticated and complicated German machinery, new to country at that time. In this process, through various intensive training programmes, the leader could develop many capable engineers. Apparently, under his leadership, the diverse workforce behaved like one family with the common goal of maximizing the generation of the power plant, taking its PLF (plant load factor) higher and higher to help the steel plant meet its production targets with quality and quantity.

Secondly, while the leader was in CPP, his endeavour to organize social activities like outdoor activities of angling expedition, parties and cultural activities on a regular basis used to ease out employees from the stress faced at the workplace. All the employees under his supervision used to be treated as members of a single family and he being given an accolade of a father figure. He would always turn up to the expectations of employees with each one being dawned with responsibilities as per their expertise. This kind of "nurturant" behaviour of the leader was not only appreciated in NALCO but also considered to be an exemplary figure for other leaders in the same industry.

While his stay as CMD in VSP, the leader was persistently facing huge challenge of commissioning the plant on 
deadline. However, his approach of empowering his team members as well as keeping a constant tab on their performance, could successfully abet the completion by November 1990 of first stage of commissioning of power plant oxygen plant, coke oven battery and all the units of 1.5 MT with a total financial implications of 8500 corers of rupees ina head of the schedule. The second stage of 1.2 million tonne was commissioned on $28^{\text {th }}$ March 1992. The achievement of success is also attributed to his ability to listen carefully to his team member's suggestions on wide range of operational issues.

In the words of a top management person:

To Sri Rath, hierarchy was an alien concept. Every man who has worked with him will affirm that he accorded everyone, junior or senior, equal respect and consideration. A good suggestion could come from anybody and would be suitably recognized. He was also quick to see that credit was given where it was due. This has invariably kept everyone satisfied.

Consistent to above discussion, it is also witnessed historically that the Odisha kings used to liberally distribute land among their soldiers (Paikias) and crown them with titles like "nayak", "pattnayak", "senanayak", and "gadanayak" in recognition of their contribution towards the state's sovereignty (Das, 2009).

Thus the hypothesis from preceding discussion follows as:

P6: An employee concern-oriented transformational leader would significantly increase the performance of transformational leadership.

\section{Discussion}

Considerable attention can be drawn through this research towards the impact of regional values on transformational leadership performance, which is an under-researched area. This study draws the frontiers of transformational leadership in a societal context wherein the diversity exists within the nation as far the cultural issues are concerned.

As argued in these studies, there are many unique features of Odisha culture which are not featured in a universal description of a transformational leader and as well as in culture specific context. Although there are component of "Unique Indian" dimensions (Singh \& Krishnan, 2005) of transformational leader in pertinent study like exhibiting expertise, and nurturant type leader coupled with personal touch, more than half of the attributes like maverick nature, social capital, risk-taking ability and act of liaising are attuned with "Unique Odisha" dimensions. Thus attributes of TL found in this study transcend Odisha culture that reflects its idiosyncratic nature. These components of TL have evolved out of underlying drives, motives and values of the individuals in societal context.

To sum up the discussion, it can also be argued that he educational compatibility with nature of industry along with same line of behaviours which are socially and regionally values can abet transformational leaders to pre-empt and combat the opposite forces arising due to technological changes, economic uncertainty, political and social milieu.

\subsection{Implications for Practice}

With the economy embarking on the process of liberalization, privatization and globalization since the early 1990s, the role of the Indian public sector has subsequently undergone a rapid change. Integration of the domestic economy with global markets has thrown up a plethora of opportunities and challenges to PSUs. Some public sector enterprises with a strategic vision are actively exploring new avenues and have increased their activities to adopt mergers, acquisitions, amalgamations, take-overs towards creating new joint ventures. Leaders with the capabilities to strengthen social networks with actors worldwide will provide competitive advantage to a firm by leveraging not only one's core competency but by also looking at others' core competencies. Even the maverick behaviour of the manager may champion new causes and events which can provide astounding results with novelty in products and services. The managers through their relational skills should maintain healthy relationships with state government officials and administrators to avoid any interruption of political bureaucracy. Thus the oxymoron attained by well performing PSUs in the late nineties can be overcome through the roles of liaising, maverick behaviour and reliance on social capital.

Other dimensions of transformational leadership like self-transcendence sharing proximity to the phrase "the greatest good for all" will contribute significantly towards corporate social responsibility. This humanistic orientation yields goodwill as well as assists in sustaining an organization. The 'nurturant' kind of leader with the inherent habit of providing personal touch need to be more in tune with the welfare of employees through innovative social programmes like the angling expedition cited in this research. Additionally, such kind of leader 
can facilitate a well-crafted succession plan and developmental programmes which are the inherent nature of a sustainable organization. Further, such developmental drivers motivate employees through the highest order of hierarchical needs called self-actualization.

Risk-taking ability and technical wizardry are invariably supporting the transformational leaders to withstand all adversities and complexities encountered in the way of operations and to go ahead and adopt candid decisions in the event of crisis and emergency. This behaviour would eventually augment the growth and development of the organization.

\subsection{Implications for Future Research with Limitations}

This pertinent study provides at least three issues which are noteworthy for exploration in future research. Needless to say, effective operationalization of transformational leadership is well integrated with societal values during the pre-liberalization period of India. Nonetheless, future study can include additional case studies to generalize the framework of transformational leadership which is regionally embedded and extends the inventory of transformational leadership in the societal context. The quantitative method can be adopted for such purpose in order to objectify the construct in societal context. Secondly, this framework signifies imprecisely towards the leader's educational background being a moderating variable which significantly influences the performance of transformational leadership in the manufacturing or metallurgical sector. Future research can upsurge with the predominant nature of educational background to be the moderator between behaviours and characteristics of transformational leadership and performance. Last but not the least, the study can also corroborate whether this framework is applicable in the post-liberalization context by comparing the inventory of transformational leaders before and after liberalization in a similar societal context.

\section{Acknowledgement}

We are highly indebted to Prof. J. B. P. Sinha for his valuable inputs and insight while developing the study. The manuscript could have remained incomplete without Mr. Bhubana Nanda Rath's permission and modest gesture to portray him as a transformational leader.

\section{References}

Acquaah, M. (2007). Managerial social capital, strategic orientation, and organizational performance in an emerging economy. Strategic Management Journal, 28(12), 1235-1255. http://dx.doi.org/10.1002/smj.632

Adler, P., \& Kwon, S. (2002). Social capital: prospects for a new concept. Academy of Management Review, 27, $18-40$.

Anonymous. (2005). Effecting change at Wyndham. Lodging Hospitality, 61(9), 46.

Annells, M. (1996). Grounded Theory Method: Philosophical Perspectives, Paradigm of Inquiry, and Postmodernism. Qualitative Health Research, 6(3). http://dx.doi.org/10.1177/104973239600600306

Baskerville, R., \& Pries-Heje, J. (1999). Grounded action research: a method for understanding IT in practice. Accounting, Management and Information Technologies, $9(1)$. http://dx.doi.org/10.1016/S0959-8022(98)00017-4

Bass, B. M. (1985). Leadership and performance beyond expectations. New York, NY: Free Press.

Bass, B. M., \& Steidlmeier, P. (1999). Ethics, character, and authentic transformational leadership behaviour. Leadership Quarterly, 10(2), 181-217. http://dx.doi.org/10.1016/S1048-9843(99)00016-8

Behling, O., \& McFillen, J. M. (1996). A syncretical model of charismatic transformational leadership. Group \& Organization Management, 21(2), 163-192. http://dx.doi.org/10.1177/1059601196212004

Bhoi, B. (2006). Prayers and Reflections trans. Siddharth Satpathy, Bhubanesawar Rupanter.

Carpenter, M. A., Geletkanycz, M. A., \& Sanders, G. M. (2004). Upper echelons research revisited: Antecedents, elements and consequences of top management team composition. Journal of Management, 30, 749-778. http://dx.doi.org/10.1016/j.jm.2004.06.001

Carpenter, M. A., Geletkanycz, M. A., \& Sanders, W. G. (2004). The upper echelons revisited: Charismatic leadership and follower effects. Journal of Organizational Behaviour, 21(7), 747-767.

Das, G. K. (2009). Odiya literary culture in the world traditions. Journal of Literature, Culture and Media Studies, 1(2), 113-120.

Das, G. (2003). Collection of rhymes trans. Gopabandhu Sahitya Mandir, Cuttack.

Dayal, I. (1999). Can Organizations Develop Leaders: A Study of Effective Leaders. New Delhi: Mittal 
Publications.

Erkutlu, H. (2008). The impact of transformational leadership on organizational and leadership effectiveness: The Turkish case. The Journal of Management Development, 27(7), 708-726. http://dx.doi.org/10.1108/02621710810883616

Gill, A. S., \& Mathur, N. (2007). Improving employee dedication and pro-social behaviour. International Journal of Contemporary Hospitality Management, 19(4), 328-334. http://dx.doi.org/10.1108/09596110710747661

Hinduan, Z., Wilson-Evered, E., Moss, S., \& Scannell, E. (2009). Leadership, work outcomes and openness to change following an Indonesian bank merger. Asia Pacific Journal of Human Resources, 47(1), 59. http://dx.doi.org/10.1177/1038411108099290

Keller, R. T. (1992). Transformational leadership and the performance of research and development project groups. Journal of Management, 18, 489-501. http://dx.doi.org/10.1177/014920639201800304

Keller, R. T. (2006). Transformational leadership, initiating structure, and substitutes for leadership: A longitudinal study of R\&D project team performance. Journal of Applied Psychology, 91, 202-210. http://dx.doi.org/10.1037/0021-9010.91.1.202

Miller, D., Droge, C., \& Toulouse, J. M. (1988). Strategic process and content as mediators between organizational context and structure. Academy of Management Journal, 31, 544-569. http://dx.doi.org/10.2307/256459

Mishra, P. K. (2010). Konarka (5th ed.). Lark books, Bhubaneswar.

Mwendia, K. (2006). Relationship of transformational leadership competencies to financial performance: As applied to the hospitality industry (Ph.D. dissertation, Capella University. Minnesota).

Nahapiet, J., \& Ghoshal, S. (1998). Social Capital, Intellectual Capital, and the Organizational Advantage. Academy of Management Review, 23(2), 242-66.

Nanda, P. K. (2006). Jagatsinghpur past and present, maritime history of Paradip. Bhubaneswar Rupanter.

Peng, M. W., \& Luo, Y. (2000). Managerial Ties and Firm Performance in a Transition Economy: The Nature of a Micro-Macro Link. Academy of Management Journal, 43, 486-501. http://dx.doi.org/10.2307/1556406

Piccolo, R. F., \& Colquitt, J. A. (2006). Transformational leadership and job behaviors: The mediating role of core job characteristics. Academy of Management Journal, 49, 327-340. http://dx.doi.org/10.5465/AMJ.2006.20786079

Piccolo, R. F., Hoffman, B. J., Bynum, B. H., \& Sutton, S. W. (2011). Person-organization value congruence: how transformational leaders influence work group effectiveness. Academy of Management Journal, 54(4), 779-796. http://dx.doi.org/10.5465/AMJ.2011.64870139

Podsakoff, P. M., \& MacKenzie, S. B. (1997). Impact of organizational citizenship behaviour on organizational performance: A Review and suggestion for future research. Human Performance, 10(2), 133-151. http://dx.doi.org/10.1207/s15327043hup1002_5

Ray, R. G., Ugbah, S. D., Brammer, C., \& DeWine, S. (1996). Communication behaviors, innovation, and the maverick leader. Journal of Leadership Studies, 3(3), 20-30. http://dx.doi.org/10.1177/107179199700300304

Schein, E. H. (1992). Organizational culture and leadership (2nd ed.). San Francisco, CA: Jossey-Bass.

Schneider, B. (1987). The people make the place. Personnel Psychology, 40, 437-453. http://dx.doi.org/10.1111/j.1744-6570.1987.tb00609.x

Schwartz, S. H. (2005a). Basic human values: Their content and structure across countries. In Tamayo, A. \& J. B. Porto (Eds.), Valores e comportamento nas organizações (Values and behavior in organizations (pp. 21-55)). Petrópolis, Brazil: Vozes.

Sabegh, J. S., \& Sharma, K. S. (1991). A system dynamics of a public sector in India. System Dynamics, 515-523.

Singh, N., \& Krishnan, V. R. (2005). Towards understanding transformational leadership in India: a grounded theory approach. The Journal of Business Perspective, 9(21), 5-17. http://dx.doi.org/10.1177/097226290500900203 
Singh, P., \& Bhandarker, A. (1990). Corporate Success and Transformational Leadership. New Delhi: Wiley Eastern.

Sinha, J. B. P. (1995). The Cultural Context of Leadership and Power. New Delhi: Sage Publications.

Strauss, A., \& Corbin, J. (1998). Basics of Qualitative Research: Techniques and Procedures for Developing Grounded Theory (2nd ed.). Sage: Thousand Oaks, CA.

Tracey, J. B., \& Hinkin, T. R. (1994). Transformational leaders in the hospitality industry. Cornell Hotel and Restaurant Administration Quarterly, 35(2), 18. http://dx.doi.org/10.1177/001088049403500213

Yin, R. K. (2008). Case Study Research: Design and Methods (4th ed.). Sage: Thousand Oaks, CA.

Yukl, G. A., \& Becker, W. S. (2006). Effective Empowerment in Organization. Organization Management Journal, 3(3), 210-231. http://dx.doi.org/10.1057/omj.2006.20

Sinha... et al. (1994). Regional Similarities and Differences in People's Beliefs, Practices and Preferences. Psychology and Developing Societies, 6(2), 131-50. http://dx.doi.org/10.1177/097133369400600204

\section{Copyrights}

Copyright for this article is retained by the author(s), with first publication rights granted to the journal.

This is an open-access article distributed under the terms and conditions of the Creative Commons Attribution license (http://creativecommons.org/licenses/by/3.0/). 